\title{
Export Process Capability Assessment Model
}

\author{
Jeremy Besson ${ }^{1}$, Antanas Mitasiunas ${ }^{2}$, Saulius Ragaisis ${ }^{3}$, \\ ${ }^{1,2}$ Vilnius University, MitSoft UAB, Lithuania, ${ }^{3}$ Vilnius University, Lithuania
}

\begin{abstract}
The process capability modeling has become a tool for systematization and codifying knowledge of process-oriented activities. Enterprise SPICE defines a domain independent integrated model for enterprise-wide assessment and continuous improvement. This paper presents the complete export process capability assessment model containing the export body of knowledge expressed in terms of SPICE conformant processes, their outcomes and base practices. The purpose of the developed model is to enable use of domain independent Enterprise SPICE model for the export process improvement.
\end{abstract}

Keywords - Application dependent process modeling, enterprise SPICE, export, process assessment model.

\section{INTRODUCTION}

The process capability modeling has become a tool for systematization and codifying knowledge of process-oriented activities. By introducing the process capability concept, it enables one to assess the predictability of activity and to improve the quality of its results. Enterprise SPICE [1] defines a domain independent integrated model for enterprise-wide assessment and continuous improvement. But application domains contain application specific knowledge that cannot be covered in width and depth needed by a domain independent process model.

This paper presents employment of SPICE conformant application dependent process modeling to export activities and the resulting complete export process capability assessment model designed as an Enterprise SPICE extension.

\section{EXPORT CAPABILITY MATURITY MODELING}

During 25 years of capability maturity modeling, hundreds of capability maturity models for wide range of application areas have been developed. But a very few attempts to create capability maturity models for export were taken. First, such a model - Export Maturity Model (EMM) [2] - was created in 2008 by the Brazilian consortium ActMinds $\AA$. EMM also defines five levels of maturity according to export readiness:

- Level 1: Interest. The company is interested in exporting, but it does not know what to whom or how.

- Level 2: Potential. The company has a clear and defined its export potential.

- Level 3: Market. The company has its export potential and the market clearly defined.

- Level 4: Strategy. The company has its operational strategy fully defined.

- Level 5: Export. The company implements its strategic plan of action abroad.
ADS - a premier trade organization that advances and promotes the UK aerospace, defense, security and space industries - had promised in 2012-2013 to create the Export Maturity model supporting ADS 21st Century Supply Chains (SC21)' companies in being globally competitive.

According to the modern approach to process maturity modeling it should be based on a process capability concept. Export process model provided here differently from EMM [2] is an export process capability model.

Export process capability assessment model was created in 2013-2014. SPICE conformant application dependent process modeling methodology [3] has been applied for modeling of export activities. Approach for Enterprise SPICE extending by inclusion of application dependent PAMs has been proposed and the model has been developed as Enterprise SPICE extension. Export process capability model motivation and composition is provided in [4]. This paper presents the export process reference model (PRM) and export process capability assessment model (PAM) slightly adjusted after the first trial by the Lithuanian company exporting medical products.

The adequacy of developed export process capability assessment model to a real export activity was confirmed export planning and operation processes and their base practices cover real export activities and provide alternatives for potential improvement.

\section{EXPORT PROCESS CATEGORY}

Export process category introduced here reflects directly the export body of knowledge in terms of all processes, their outcomes and base practices satisfying requirements of ISO/IEC 15504-2 for process reference models (PRM) and process assessment models (PAM). The official US government resource for small and medium-sized business [5], Australian Export Handbook of the Australian Institute of Export [6] and Exporter Guide of Lithuanian Economic Development Agency [7] have been taken as the main sources of domain body of knowledge.

All export related activities could be distributed into two stages: preparation for export and exporting itself. Therefore, two corresponding subcategories of processes have been introduced. The PAM level definition of a process consists of process identifier, process name, process outcomes, and base practices related to outcomes they support. Processes of Export Preparation and Export Operation subcategories are listed in Table I and II, respectively. 
TABLE I

PROCESSES OF EXPORT PREPARATION SUBCATEGORY

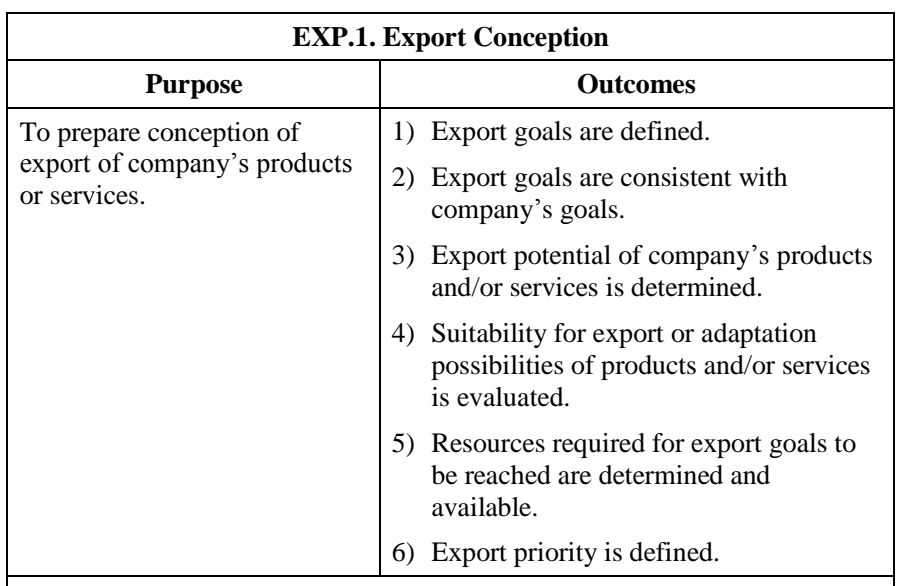

Base Practices

BP.1: Define export goals. Define company's generic export goals (for instance, market diversification, market expansion of niche products or services, sales volume extension, client circle extension, realization price/quality ratio optimization, harmonization with global trends, opportunities expansion). [Outcome: 1]

BP.2: Align export goals with company's goals. Align export goals with company's goals balancing export's benefits and costs during period of time. [Outcome: 2]

BP.3: Determine export potential of company's products and/or services. Determine products and services having biggest export potential. [Outcome: 3]

BP.4: Estimate resources for product and/or service preparation for export. Estimate resources for export preparation of products and/or services having the biggest export potential. [Outcomes: 4 and 5]

BP.5: Evaluate the changes in company's business caused by export.

Evaluate company's performance and resources needed for export.

[Outcomes: 2 and 5]

BP.6: Define export priority among all company's activities. Determine the export priority of products and/or services in comparison with company's other activities. [Outcome: 6]

\begin{tabular}{|c|c|}
\hline \multicolumn{2}{|c|}{ EXP.2. Determining Export Potential } \\
\hline Purpose & Outcomes \\
\hline $\begin{array}{l}\text { To identify and evaluate } \\
\text { internal and external obstacles, } \\
\text { interferences and opportunities } \\
\text { for product or service export } \\
\text { that could prevent or } \\
\text { significantly influence move to } \\
\text { foreign markets. }\end{array}$ & $\begin{array}{l}\text { 1) Negative criteria that pose } \\
\text { insurmountable barriers to export are } \\
\text { identified. } \\
\text { 2) Hindrances that have a negative impact } \\
\text { on export are identified. } \\
\text { 3) Positive criteria that mostly influence } \\
\text { the export success are identified. } \\
\text { 4) Potential product/service export is } \\
\text { evaluated according to identified } \\
\text { internal negative criteria, substantial } \\
\text { obstacles and success factors. } \\
\text { 5) The possible export markets are scanned } \\
\text { according to external criteria. } \\
\text { 6) The export assessment results are } \\
\text { documented and presented for decision } \\
\text { making. }\end{array}$ \\
\hline
\end{tabular}

\section{Base Practices}

BP1: Identify internal negative criteria. Identify exporting country's internal negative criteria, if exist (permanent or temporary legal-normative regulation), whose presence discontinues export plan preparation and execution. [Outcome: 1]

BP2: Identify external negative criteria. Identify external negative criteria of the export country, if exist (absence of demand or necessary infrastructure, permanent or temporary legal-normative regulation, area of military conflicts, criminogenic situation, etc.), whose presence discontinues export plan preparation and execution. [Outcome: 1]

BP3: Identify internal hindrances. Identify exporting country's internal hindrances (absence of risk insurance, price level), whose presence considerably influences export. [Outcome: 2]

BP4: Identify external hindrances. Identify external hindrances of the export country (small demand, big competition and import tax, legal regulation, supervisory bodies, corruption level, settlement issues), whose presence considerably influences export. [Outcome: 2]

BP5: Identify internal positive criteria. Identify exporting country interna possibilities and strengths that ensure export potential and whose presence positively influences export (high quality, low cost, free capacity). [Outcome: 3]

BP6: Identify external positive criteria. Identify external positive factors of export country that ensure export of products/services (existing quality certificates, low price, favourable assessments). [Outcome: 3]

BP7: Evaluate internal criteria and hindrances. Evaluate presence of internal positive and negative criteria and hindrances for export of products/services. [Outcome: 4]

BP8: Scan market. Scan product/service markets of export countries and regions according to external criteria and hindrances to assess export possibilities and create the list of export markets. [Outcome: 5]

BP9: Evaluate documents. Assess documents of product/service export and results for export decision making. [Outcome: 6]

\begin{tabular}{|l|l|}
\hline \multicolumn{2}{|c|}{ EXP.3. Developing Export Strategy } \\
\hline \multicolumn{1}{|c|}{ Purpose } & \multicolumn{1}{c|}{ Outcomes } \\
\hline $\begin{array}{l}\text { Based on export goals and } \\
\text { current constraints, to update } \\
\text { the company's business } \\
\text { strategy so that export goals } \\
\text { will be achieved. }\end{array}$ & $\begin{array}{l}\text { 1) } \begin{array}{l}\text { The company's internal strategy that } \\
\text { creates preconditions for export is } \\
\text { updated. }\end{array} \\
\text { 2) } \begin{array}{l}\text { Available resources for export activities } \\
\text { are identified. }\end{array} \\
\text { 3) Enterprise external strategy for export is } \\
\text { defined. } \\
\text { 4) Company's external presentation } \\
\text { strategy is formed. } \\
\text { 5) Export potential is evaluated. } \\
\text { 6) The export market potential is evaluated. } \\
\text { 7) Export strategy compatible with the } \\
\text { company's objectives and resources is } \\
\text { defined. }\end{array}$ \\
\hline \\
Base Practices
\end{tabular}

BP1: Analyze current status. Analyze internal and external factors of current status of company's intended export using secondary (publicly available, generic) and primary (direct, specialized, and individual) sources of information. [Outcomes: 1-5]

BP2: Perform SWOT analysis. Perform intended export SWOT analysis. [Outcomes: 1-4]

BP3: Update company's internal strategy. Prepare updated company's strategy of internal activity to create preconditions for export of products/services. [Outcome: 1]

BP4: Assess resources. Assess company's resources needed for export. [Outcome: 2]

BP5: Develop company's external presentation strategy. Develop company's external presentation strategy for export countries, including company's strengths and communication difficulties in export markets. [Outcomes: 3, 4]

BP6: Assess export's potential. Assess company's products/services from point of view of export potential. [Outcome: 5]

BP7: Assess export's market. Assess correspondence of export market and company's products/services to be exported. [Outcome: 6]

BP8: Develop export strategy. Develop a product/service export strategy in accordance with company's goals and resources. [Outcome: 7] 


\begin{tabular}{|c|c|}
\hline \multicolumn{2}{|c|}{ EXP.4. Export Decision Making } \\
\hline Purpose & Outcomes \\
\hline \multirow{7}{*}{$\begin{array}{l}\text { According to company's goals } \\
\text { and export strategy, to } \\
\text { evaluate internal and external } \\
\text { factors determining } \\
\text { product/service export and to } \\
\text { take decision concerning } \\
\text { export plan development and } \\
\text { implementation. }\end{array}$} & 1) Opportunities to export are identified. \\
\hline & $\begin{array}{l}\text { 2) Target user groups, requirements, and } \\
\text { the level of demand are identified. }\end{array}$ \\
\hline & $\begin{array}{l}\text { 3) Suitability for foreign markets of } \\
\text { available products/services and the level } \\
\text { of required customization are evaluated. }\end{array}$ \\
\hline & $\begin{array}{l}\text { 4) The competitive environment - quality } \\
\text { and price level of products/services in } \\
\text { foreign markets - is estimated. }\end{array}$ \\
\hline & $\begin{array}{l}\text { 5) The costs of product/service export } \\
\text { preparation, publicity and export are } \\
\text { evaluated. }\end{array}$ \\
\hline & $\begin{array}{l}\text { 6) The results of product/service export } \\
\text { risk analysis are evaluated. }\end{array}$ \\
\hline & $\begin{array}{l}\text { 7) A decision on exporting products or } \\
\text { services is taken. }\end{array}$ \\
\hline \multicolumn{2}{|c|}{ Base Practices } \\
\hline
\end{tabular}

BP1: Assess export feasibility. Assess feasibility of entrance to a foreign export market, based on an export strategy developed and scanning results of export market. [Outcome: 1]

BP2: Identify target groups. Identify product/service customers and end user target groups, normative and user requirements. [Outcome: 2]

BP3: Assess readiness. Assess readiness of products/services for export market and extent of adaptation needed. [Outcome: 3]

BP4: Assess the competitive environment. Assess functionality, quality, price level or other products/services existing in an export market. [Outcome: 4]

BP5: Assess costs. Assess the costs of product/service preparation for export, marketing, and exporting, [Outcome: 5]

BP6: Assess risks. Identify product/service export risk factors, assess their probability and impact to company's activities, and envisage risk mitigation measures. [Outcome: 6]

BP7: Make the decision. Make a positive or negative decision concerning product/service export plan development and execution. [Outcome: 7]

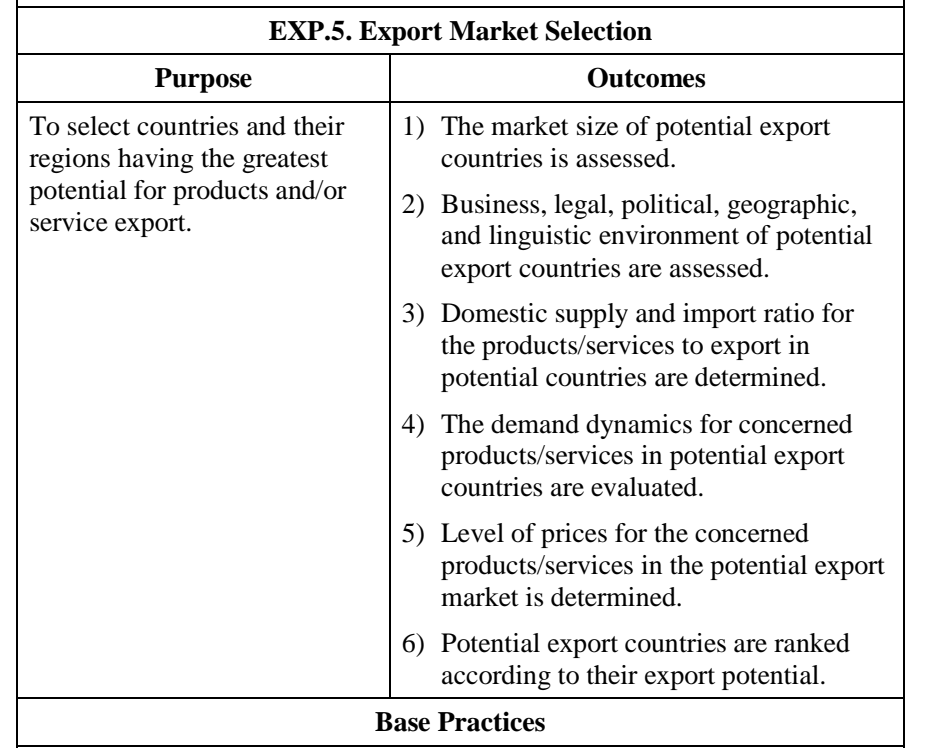

BP1: Identify importing markets. Identify countries or regions most importing products/ services to be exported by the company. [Outcome: 1]

BP2: Assess the export market volume. Assess market volume of company's products/services intended to be exported to potential export countries or regions. [Outcome: 1]

BP3: Assess the export market context. Assess business conditions, legal, political, geographic and linguistic environment in potential export

\section{countries/regions. [Outcome: 2]}

BP4: Determine a ratio of internal supply/import. Determine ratio of internal supply and import of products/services intended to be exported to potential export countries/regions. [Outcome: 3]

BP5: Assess demand dynamics. Assess demand dynamics of intended to export products/ services in potential export's countries/regions. [Outcome: 4]

BP6: Assess a price level. Assess the price level of products/services intended to be exported to potential export's countries/regions. [Outcome: 5] BP7: Rate the export market. Rate potential export countries/regions to which products/services are to be exported. [Outcome: 6]

\section{EXP.6. Distribution Channel Selection}

\begin{tabular}{|l|l|}
\hline \multicolumn{1}{|c|}{ Purpose } & \multicolumn{1}{c|}{ Outcomes } \\
\hline $\begin{array}{l}\text { To identify a set of distribution } \\
\text { channels and to select the most } \\
\text { suitable distribution channels } \\
\text { based on the established } \\
\text { criteria. }\end{array}$ & $\begin{array}{l}\text { 1) } \begin{array}{l}\text { Direct and indirect distribution channels } \\
\text { are identified. }\end{array} \\
\text { 2) } \begin{array}{l}\text { Internal and external restrictions of } \\
\text { distribution channels are identified. }\end{array} \\
\text { 3) Internal and external criteria for } \\
\text { distribution channel evaluation are } \\
\text { defined. }\end{array}$ \\
& 4) $\begin{array}{l}\text { Distribution channel alternatives are } \\
\text { evaluated according to the defined } \\
\text { criteria. }\end{array}$ \\
& 5) $\begin{array}{l}\text { The most useful alternatives of } \\
\text { distribution channels are identified and } \\
\text { selected. }\end{array}$ \\
\hline
\end{tabular}

Base Practices

BP1: Identify direct distribution channels. Identify actually or potentially feasible direct distribution channels without intermediaries (opening representation, service point establishment, purchase of operating lease services). [Outcome: 1]

BP2: Identify indirect distribution channels. Identify possible indirect distribution channels based on intermediaries (partnership agreement, supply on consignment). [Outcome: 1]

BP3: Identify internal restrictions of the distribution channels. Identify restriction for selection of direct and indirect distribution channels caused by exporting company (insufficient language knowledge in the export market, absence of suitable personnel). [Outcome: 2]

BP4: Identify external restrictions of the distribution channels. Identify restriction for selection of direct and indirect distribution channels caused by the export market (compulsory sales license) [Outcome: 2]

BP5: Define internal criteria. Define criteria for selection of direct and indirect distribution channels caused by a company. [Outcome: 3]

BP6: Define external criteria. Define criteria for selection of direct and indirect distribution channels caused by the export market [Outcome: 3 ]

BP7: Assess distribution channels. Assess identified distribution channels according to the identified internal and external restrictions and assessment criteria. [Outcome 4]

BP8: Select distribution channels. Select one or more most beneficial distribution channels based on assessment results. [Outcome 5]

\begin{tabular}{|c|c|}
\hline \multicolumn{2}{|c|}{ EXP.7. Commercial contact search } \\
\hline Purpose & Outcomes \\
\hline $\begin{array}{l}\text { To find qualified buyers for } \\
\text { products and/or services and } \\
\text { business partners abroad. }\end{array}$ & $\begin{array}{l}\text { 1) Individual and business mission } \\
\text { contacts with interested business } \\
\text { partners are established. }\end{array}$ \\
\hline & $\begin{array}{l}\text { 2) Foreign potential buyers and business } \\
\text { partners in target groups are identified. }\end{array}$ \\
\hline & $\begin{array}{l}\text { 3) Marketing material for potential } \\
\text { customers and business partners is } \\
\text { prepared. }\end{array}$ \\
\hline & $\begin{array}{l}\text { 4) A list of potential buyers and business } \\
\text { partners with their contact information } \\
\text { is prepared. }\end{array}$ \\
\hline
\end{tabular}


5) The marketing material is provided to potential customers and business partners.

6) Based on the interest of potential buyers and business partners' responses, additional information is provided, and contacts are maintained.

\section{Base Practices}

BP1: Identify methods for individual contact search. Identify methods suitable for individual contact search (list of target contact address composition, dispatch of requests and newsletters, meetings with potential clients and business partners). [Outcome: 1]

BP2: Identify methods for organizational contact search. Identify methods suitable for organizational contact search (attending international exhibitions, contacts fairs, business missions etc.). [Outcome: 1]

BP3: Establish export contacts. Establish export contacts with potential buyers and business partners using suitable search methods for the company contacts. [Outcome: 1]

BP4: Identify target groups. Identify target groups of foreign potential buyers and business partners to whom export products/services can be exported. [Outcome: 2]

BP5: Prepare marketing material. Prepare marketing material on products/services to be exported according to target groups of buyers and business partners. [Outcome: 3 ]

BP6: Collect contact data. Collect a list of potential buyers and business partners, including contact data. [Outcome: 4]

BP7: Provide marketing material. Provide developed marketing material on products/services to potential buyers and business partners. [Outcome: 4]

BP8: Maintain contacts. Maintain contacts developed by dispatch of reminders, additional and updated information on proposal based on reply received from interested potential buyers and business partners. [Outcome: 5]

\begin{tabular}{|c|c|}
\hline \multicolumn{2}{|c|}{ EXP.8. Export Planning } \\
\hline Purpose & Outcomes \\
\hline
\end{tabular}

\begin{tabular}{|l|l|}
\hline To develop actions, measures & 1) The company's current internal and
\end{tabular} and deadlines for achievement external situation is analyzed in the of product and/or service export goals. context of the planned export.

2) Export marketing strategy is prepared

3) Preliminary sales models are prepared.

4) Export activities are defined.

5) Export budget is prepared.

6) Export plan is prepared and documented.

\section{Base Practices}

BP1: Establish export goals. Establish product/service export goals and the main criteria for their achievement. [Outcome: 1]

BP2: Analyze an internal situation. Analyze the company's internal situation in the context of planned export. [Outcome: 1]

BP3: Analyze an external situation. Analyze the company's external situation in the context of export market. [Outcome: 3 ]

BP4: Select an export market. Select and evaluate the requirements of product/service target market. [Outcome: 2]

BP5: Select products/services. Select products/services to be exported to the target market. [Outcome: 2]

BP6: Customize products/services. Customize products/services to be exported according to the requirements of target market. [Outcome: 2]

BP7: Establish export models. Establish a product/service direct export model via partners or intermediaries. [Outcomes: 2, 3]

BP8: Determine export terms and conditions. Determine terms and conditions of product delivery/service provision. [Outcome: 2]

BP9: Determine export activities. Determine product/service export activities, results, schedule, empowerment and responsibilities. [Outcome: 4]
BP10: Establish an export budget. Define and allocate financial and human resources for performance of export activities. [Outcome: 5]

BP11: Develop an export plan. Prepare and document product/service export plan, integrating export activities and budget determined. [Outcome: 6]

TABLE II

PROCESSES OF EXPORT OPERATION SUBCATEGORY

\begin{tabular}{|l|l|}
\hline \multicolumn{2}{|c|}{ EXO.1. Export Agreement Management } \\
\hline \multicolumn{1}{|c|}{ Purpose } & \multicolumn{1}{c|}{ Outcomes } \\
\hline $\begin{array}{l}\text { To tune up and } \\
\text { approve an agreement } \\
\text { for product/service } \\
\text { export defining } \\
\text { clearly and } \\
\text { unequivocally } \\
\text { expectations, rights, } \\
\text { duties and } \\
\text { responsibilities of } \\
\text { both parties, } \\
\text { specifying products/ } \\
\text { services delivered, } \\
\text { their price and } \\
\text { payment conditions. }\end{array}$ & $\begin{array}{l}\text { 1) } \\
\text { The country's law for an export agreement is } \\
\text { arranged. }\end{array}$ \\
$\begin{array}{l}\text { 2) } \begin{array}{l}\text { Object of the agreement and its parameters are } \\
\text { defined. }\end{array} \\
\text { The jurisdiction of the resolution of disputes on } \\
\text { possible settlement agreements is arranged. }\end{array}$ \\
$\begin{array}{l}\text { 4) } \begin{array}{l}\text { An agreement is prepared in accordance with the } \\
\text { requirements of the applicable country's law. } \\
\text { agreement performance is envisaged in the }\end{array} \\
\text { contract. } \\
\text { 6isk mitigation measures concerning export } \\
\text { agreement performance are envisaged in the } \\
\text { contract. }\end{array}$ \\
\hline \multicolumn{1}{|c|}{ 7) $\begin{array}{l}\text { Export agreement is arranged, reviewed and } \\
\text { approved by all involved parties. }\end{array}$} \\
\hline
\end{tabular}

BP1: Arrange agreement country's law. Select and arrange country's law applicable to the product/service export agreement by the export parties. [Outcome: 1]

BP2: Define agreement's object. Define agreement's object and the main parameters (products/services, delivery volume and schedule, principles of price determination etc.). [Outcome: 2]

BP3: Arrange dispute resolution. Arrange the jurisdiction of dispute resolution concerning a product/service export agreement when agreement parties cannot resolve dispute with each other. [Outcome: 3]

BP4: Prepare an agreement. Prepare provisions of the product/service export agreement according to the requirements of arranged agreement country's law. [Outcome: 4]

BP5: Envisage a monitoring mechanism. Envisage a monitoring mechanism of product/service export performance in accordance with the agreement. [Outcome: 5]

BP6: Envisage risk management. Envisage risk assessment and mitigation measures of product/service export agreement performance. [Outcome: 6]

BP7: Approve an export agreement. Review, arrange and approve the export agreement by all involved parties. [Outcome: 7]

\begin{tabular}{|c|c|}
\hline \multicolumn{2}{|c|}{ EXO.2. Negotiation of Delivery Terms } \\
\hline Purpose & Outcomes \\
\hline $\begin{array}{l}\text { To reconcile } \\
\text { commitments of seller } \\
\text { and buyer and to } \\
\text { submit them for } \\
\text { approval by an export } \\
\text { agreement. }\end{array}$ & $\begin{array}{l}\text { 1) The requirements for the product/service } \\
\text { preparation, transfer or provision are defined. } \\
\text { 2) The license and other necessary permits are ready. } \\
\text { 3) Requirements for product transportation/service } \\
\text { provision and the insurance are set. } \\
\text { 4) Costs of product transportation/service provision } \\
\text { are distributed and allocated. } \\
\text { 5) Product transportation/service provision risk } \\
\text { shift from a seller to a buyer is defined. } \\
\text { 6) Product/service transfer and acceptance } \\
\text { procedures are defined. } \\
\text { 7) Seller and buyer communication mechanism is } \\
\text { defined. }\end{array}$ \\
\hline & Base Practices \\
\hline
\end{tabular}


BP1: Define requirements for products/services. Define and arrange requirements for product/service preparation and transfer/provision. [Outcome: 1]

BP2: Prepare licenses and permits. Prepare licenses and other permits needed. [Outcome: 2]

BP3: Determine requirements for transportation. Determine requirements for transportation and insurance of exported products/services. [Outcome: 3]

BP4: Distribute and allocate transportation costs. Arrange, distribute and allocate costs of transportation and insurance between export agreement parties. [Outcome: 4]

BP5: Define transition of responsibility. Define momentum of product transportation/service delivery risk transition from a seller to a buyer. [Outcome: 5]

BP6: Define transfer and acceptance procedure. Define, arrange and submit transmission-reception procedure of products/services to be included into an export agreement. [Outcome: 6]

BP7: Define a communication mechanism. Define, arrange and submit a communication mechanism between a seller and a buyer to be included into an export agreement. [Outcome: 7]

\begin{tabular}{|c|c|}
\hline \multicolumn{2}{|r|}{ EXO.3. Pricing } \\
\hline Purpose & Outcomes \\
\hline $\begin{array}{l}\text { To create pricing } \\
\text { policy of products } \\
\text { and/or services, to } \\
\text { reconcile price and } \\
\text { payment conditions } \\
\text { with a buyer and to } \\
\text { submit them for } \\
\text { approval by an export } \\
\text { agreement. }\end{array}$ & $\begin{array}{l}\text { 1) Seller's pricing strategy is developed. } \\
\text { 2) The factors influencing the price, including } \\
\text { exchange rate fluctuations, are identified. } \\
\text { 3) A pricing method is selected. } \\
\text { 4) Purpose and types of price discounts are identified. } \\
\text { 5) The target price for the export contract is } \\
\text { established. } \\
\text { 6) The final price is arranged with the customer and } \\
\text { provided for approval by an export contract. } \\
\text { 7) The conditions of payment for export are } \\
\text { arranged with the buyer and provided for } \\
\text { approval by an export contract. }\end{array}$ \\
\hline
\end{tabular}

\section{Base Practices}

BP1: Develop a pricing strategy. Develop a pricing strategy of exported products/services taking into account alternatives: less than competitors' price, orientation to a market price, bigger than competitors' price stressing the quality and uniqueness, to vary assortment seeking statistical sustainability, establish unfavorable for competitors price etc. [Outcome: 1]

BP2: Identify price factors. Identify final price factors of exported products/services by assessing alternatives: conjuncture of supply and demand, competitors' prices for analogous products/services, image of exported products/services, order of settlement exemption, exporter's financial status, negotiator's capabilities etc. [Outcome: 2]

BP3: Select a pricing method. Select price determination method of exported products/services by assessing alternatives: orientation to costs, orientation to demand, orientation to competitors, or their combination. [Outcome: 3]

BP4: Identify a discount purpose. Identify a discount purpose by assessing alternatives: increase turnover, increase buyers' loyalty, optimize individual orders, optimize order flow distribution in time, optimize financial flows etc. [Outcome: 4]

BP5: Identify discount types. Identify a discount type by assessing alternatives: quantity discount, season discount, loyalty discount, settlement discount etc. [Outcome: 4]

BP6: Identify export price type. Identify export price type to be included in an export agreement by assessing alternatives: fixed price, fixed price by separate agreement, arranged variable price within limits of increased expenses after arrangement etc. [Outcome: 5]

BP7: Arrange the price. Arrange and submit the final price of exported products/services for export agreement conclusion. [Outcome: 6]

BP8: Arrange payment terms. Arrange and submit payment terms for export agreement conclusion. [Outcome: 7]

\begin{tabular}{|c|c|}
\hline \multicolumn{2}{|r|}{ EXO.4. Delivery Preparation } \\
\hline Purpose & Outcomes \\
\hline $\begin{array}{l}\text { To ensure availability } \\
\text { of products and/or } \\
\text { services for their } \\
\text { recipient. }\end{array}$ & $\begin{array}{l}\text { 1) The product or service composition is defined. } \\
\text { 2) Products or services are complete of } \\
\text { components. } \\
\text { 3) The product or service documentation is defined } \\
\text { and developed. } \\
\text { 4) Mechanism and medium for product or service } \\
\text { delivery/ presentation are defined. } \\
\text { 5) Evaluation criteria for the product or service } \\
\text { suitability for export are defined. } \\
\text { 6) Product or service suitability assessment for } \\
\text { export according to the defined criteria is carried } \\
\text { out. }\end{array}$ \\
\hline & Base Practices \\
\hline
\end{tabular}

BP1: Define composition. Define composition of exported products and/or services. [Outcome: 1]

BP2: Develop documentation. Develop user documentation of exported products and/or services. [Outcome: 3 ]

BP3: Complete products/services. Complete products and/or services to be exported. [Outcome: 2]

BP4: Define a delivery mechanism and medium. Define a delivery mechanism and medium for products and/or services to be exported (delivery to buyer's premise, dispatch by post, download from a website etc.) [Outcome: 4]

BP5: Define assessment criteria. Define assessment criteria for suitability of products and/or services to be exported. [Outcome: 5]

BP6: Assess suitability for export. Assess suitability for export of products and/or services according to the defined assessment criteria. [Outcome: 6]

\begin{tabular}{|l|l|}
\hline \multicolumn{1}{|c|}{ EXO.5. Shipping Management } \\
\hline \multicolumn{1}{|c|}{ Purpose } & \multicolumn{1}{c|}{ Outcomes } \\
\hline $\begin{array}{l}\text { To select the most } \\
\text { suitable shipping } \\
\text { method and carrier or } \\
\text { forwarder for product } \\
\text { export and conclude } \\
\text { an agreement for } \\
\text { product } \\
\text { transportation. }\end{array}$ & $\begin{array}{l}\text { 1) } \begin{array}{l}\text { Criteria concerning shipping alternative } \\
\text { assessment are defined. }\end{array} \\
\text { The most appropriate type of shipping according } \\
\text { to the defined criteria is selected. }\end{array}$ \\
3) $\begin{array}{l}\text { Criteria concerning carrier or forwarder } \\
\text { alternatives are defined. }\end{array}$ \\
4) $\begin{array}{l}\text { The most appropriate carrier or forwarder } \\
\text { according to the defined criteria is selected. }\end{array}$ \\
5) $\begin{array}{l}\text { Shipping contract with the selected carrier or } \\
\text { forwarder is made. }\end{array}$ \\
6) $\begin{array}{l}\text { Transport service eligibility criteria are defined } \\
\text { and their monitoring is organized. }\end{array}$
\end{tabular}

\section{Base Practices}

BP1: Define shipping criteria. Define selection criteria for exported product shipping type. [Outcome: 1]

BP2: Select shipping type. Select the product shipping type according to the defined selection criteria. [Outcome: 2]

BP3: Define carrier selection criteria. Define selection criteria of exported product carrier and/or forwarder according to the selected product shipping type. [Outcome: 3]

BP4: Select a carrier. Select exported product carrier and/or forwarder of selected shipping type according to the defined selection criteria. [Outcome: 4] BP5: Define transport service eligibility criteria. Define the assessment criteria of exported product transport service eligibility[Outcome: 5]

BP6: Conclude a shipping contract. Conclude a shipping service contract with the selected carrier and/or forwarder. [Outcome: 5]

BP7: Monitor shipping service eligibility. Monitor eligibility of shipping services of exported products according to the defined criteria. [Outcome: 6 ] 


\begin{tabular}{|c|c|}
\hline \multicolumn{2}{|r|}{ EXO.6. Exporting Services } \\
\hline Purpose & Outcomes \\
\hline \multirow{6}{*}{$\begin{array}{l}\text { To provide the } \\
\text { services that meet the } \\
\text { contractual } \\
\text { requirements. }\end{array}$} & 1) Service delivery strategy is defined. \\
\hline & $\begin{array}{l}\text { 2) The proper conditions of the service functioning in } \\
\text { the use environment are identified and evaluated. }\end{array}$ \\
\hline & $\begin{array}{l}\text { 3) Service equipment within its operating } \\
\text { environment is tested. }\end{array}$ \\
\hline & $\begin{array}{l}\text { 4) Criteria of the correct operation of services are } \\
\text { set and monitored. }\end{array}$ \\
\hline & $\begin{array}{l}\text { 5) Service delivery equipment in the use } \\
\text { environment is operational. }\end{array}$ \\
\hline & $\begin{array}{l}\text { 6) Help and advice for users are provided under the } \\
\text { agreement. }\end{array}$ \\
\hline
\end{tabular}

\section{Base Practices}

BP1: Define a service delivery strategy. Define, arrange and maintain a strategy of company's exported service provision. [Outcome: 1]

BP2: Define service functioning conditions. Determine and assess suitability of service operation conditions in the environment of service use. [Outcome: 2]

BP3: Test service delivery equipment. Test service operation equipment in the environment of service use. [Outcome: 3 ]

BP4: Determine service delivery criteria. Determine and monitor service provision suitability criteria in the environment of service use. [Outcome: 4]

BP5: Ensure a service operation. Ensure the proper operation of service provision equipment in the environment of service use. [Outcome: 5]

BP6: Help users. Provide help and consultations to users of exported services according to an agreement. [Outcome: 6]

\begin{tabular}{|l|l|}
\hline \multicolumn{1}{|c|}{ EXO.7. Export Documentation } \\
\hline \multicolumn{1}{|c|}{ Purpose } & \multicolumn{1}{c|}{ Outcomes } \\
\hline $\begin{array}{l}\text { To prepare documents } \\
\text { of product and/or } \\
\text { service export for } \\
\text { cross border and/or at } \\
\text { destination export } \\
\text { transactions. }\end{array}$ & $\begin{array}{l}\text { 1) } \text { Customs documents are prepared. } \\
\text { 2nternational freight shipping transport } \\
\text { documents are available. }\end{array}$ \\
& $\begin{array}{l}\text { 3) } \begin{array}{l}\text { Trading International Carriage documents are } \\
\text { prepared. }\end{array} \\
\text { 4) International freight product certificates are } \\
\text { available. }\end{array}$ \\
\hline \multicolumn{1}{|c|}{ Base Practices } \\
\hline
\end{tabular}

BP1: Prepare customs declarations. Prepare customs declaration for product export to third countries (outside the EU). [Outcome: 1]

BP2: Provide Intrastat customs declaration. Provide monthly a simplified Intrastat customs declaration about exported products to the EU Member States. [Outcome: 1]

BP3: Prepare international freight shipping documents. Prepare international freight shipping consignment for goods delivery according to contract indicating a sender's assignment to a carrier to deliver the goods for foreign receiver and confirming that products are submitted for transportation and carrier's responsibility for freight entrusted shipment. Depending on shipment type a consignment can be international road transport, railway transport, maritime, or air transport consignment. [Outcome: 2]

BP4: Prepare international freight trade documents. Prepare international freight trade shipment documents: Trading (consular) invoice; Invoice and VAT invoice; Packing sheet. [Outcome: 3]

BP5: Prepare international freight product certificates. Prepare compulsory documents for products established by legal acts of international freight countries and international standards: quality certificates, certificates of origin, veterinary certificate, phytosanitary certificate and voluntary certificates agreed by a mutual agreement. [Outcome: 4]

BP6: Prepare storage documents. Conclude agreement for product storage and warehousing, if applicable, that define the rights and obligations of storekeeper and the fact of product transfer by: certificate of freight

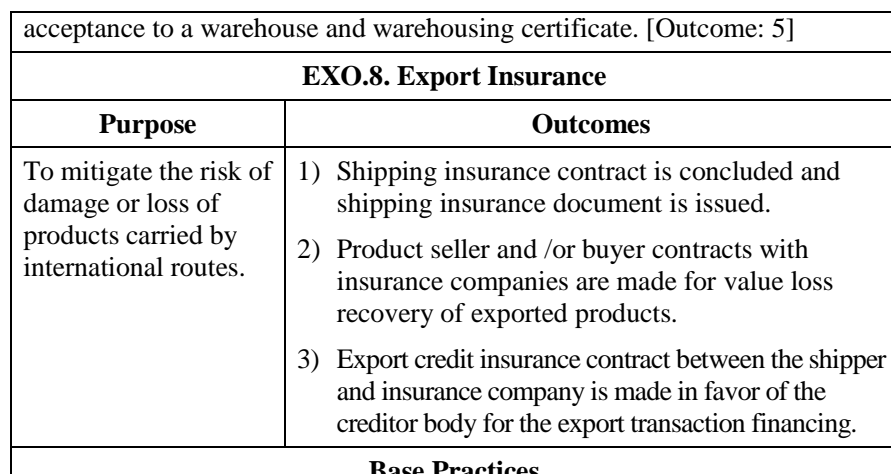

BP1: Conclude shipping insurance agreement. Conclude simple or general transport insurance agreement for exported product seller or receiver depending on Incoterms determined in an export contract. Remark: in the EU transport insurance is obligatory. [Outcome: 1]

BP2: Possess a shipping insurance document. Receive a simple or general transport insurance policy for exported product seller or receiver depending on Incoterms determined in an export contract and on this basis an insurance certificate for each transport. [Outcome: 1]

BP3: Insure products for export. Conclude insurance agreement for exported product seller or receiver depending on Incoterms determined in an export contract with insurance companies for possible product damage and loss of full or part product value. [Outcome: 2]

BP4: Insure an export credit. Insure an export credit agreement for the benefit of financing institution and submit a credit insurance policy to credit provider. [Outcome: 3]

\begin{tabular}{|c|c|}
\hline \multicolumn{2}{|r|}{ EXO.9. Settlement Processing } \\
\hline Purpose & Outcomes \\
\hline \multirow{11}{*}{$\begin{array}{l}\text { To ensure a smooth } \\
\text { exchange of goods } \\
\text { and/or services and to } \\
\text { minimize the risk of } \\
\text { failure to comply } \\
\text { commitments. }\end{array}$} & 1) Potential settlement methods are identified. \\
\hline & 2) Mutual trust level of trading partners is \\
\hline & \\
\hline & 3) The importer's financial situation is assessed. \\
\hline & $\begin{array}{l}\text { 4) Legal, political and social environment of the } \\
\text { export destination in terms of settlement } \\
\text { methods are evaluated. }\end{array}$ \\
\hline & $\begin{array}{l}\text { 5) Existing ways of settlement tradition and level of } \\
\text { competition are assessed. }\end{array}$ \\
\hline & $\begin{array}{l}\text { 6) Potential settlement methods are compared } \\
\text { according to the selected export scenario. }\end{array}$ \\
\hline & $\begin{array}{l}\text { 7) Obligations to ensure the potential types of } \\
\text { guaranty are identified. }\end{array}$ \\
\hline & $\begin{array}{l}\text { 8) Potential warranty types are compared according } \\
\text { to the selected export scenario. }\end{array}$ \\
\hline & $\begin{array}{l}\text { 9) Method of settlement and the type of guaranty for } \\
\text { commitment ensuring are selected and arranged. }\end{array}$ \\
\hline & $\begin{array}{l}\text { 10) Assessment criteria of financial settlement } \\
\text { status are established and monitored. }\end{array}$ \\
\hline
\end{tabular}

\section{Base Practices}

BP1: Identify settlement methods. Identify settlement methods for exported products/services (advance payment, open account, documentary collection, letter of credit etc.) [Outcome: 1]

BP2: Evaluate payment methods. Assess settlement methods from the point of view of security and costs. [Outcome: 1]

BP3: Assess mutual trust. Assess mutual trust of exporter and importer based on available information to determine the level of guaranty needed. [Outcome: 2]

BP4: Assess importer's financial status. Assess the financial status of importer based on available information to optimize a ratio of settlement security and costs. [Outcome: 3]

BP5: Evaluate export destination environment. Assess settlement methods according to positive and negative criteria and hindrances based on 
export destination country's legal, political and social environment [Outcome: 4]

BP6: Assess export destination competitiveness environment. Assess competitive environment of export destination country to determine the balance of settlement methods acceptable for an exporter and an importer. [Outcome: 5]

BP7: Assess export country's traditions on payment methods. Assess settlement methods practiced in product/service export destination country. [Outcome: 5]

BP8: Define assessment criteria of payment methods. Define assessment criteria of settlement methods for an export destination country. [Outcome: 6]

BP9: Compare a payment method. Compare potential settlement methods according to the defined criteria. [Outcome: 6]

BP10: Identify assurance methods for payment obligations. Identify assurance methods of settlement obligations according to settlement methods. [Outcome: 7]

BP11: Compare assurance methods for payment obligations. Compare assurance methods of settlement obligations for potential settlement methods according to an actual export scenario. [Outcome: 8]

BP12: Select payment and assurance methods for payment obligations. Select and arrange settlement methods and assurance methods of settlement obligations between an exporter and an importer. [Outcome: 8]

BP13: Define assessment criteria of settlement status. Define assessment criteria of settlement status for exported products/services. [Outcome: 9]

BP14: Monitor financial settlement. Monitor settlement status according to assessment criteria of the defined settlement status. [Outcome: 10]

\begin{tabular}{|l|l|}
\hline \multicolumn{1}{|c|}{ PXrpose } & \multicolumn{1}{c|}{ Outcomes } \\
\hline $\begin{array}{l}\text { To ensure circulating } \\
\text { assets for export of } \\
\text { products and/or } \\
\text { services. }\end{array}$ & $\begin{array}{l}\text { 1) } \begin{array}{l}\text { The exporter's needs for external funding are } \\
\text { evaluated. }\end{array} \\
\text { 2) } \begin{array}{l}\text { Potential export financing methods are } \\
\text { identified. }\end{array} \\
\text { 3) Potential export financing methods are compared } \\
\text { according to the selected export scenario. }\end{array}$ \\
& $\begin{array}{l}\text { 4) } \begin{array}{l}\text { The most appropriate way of financing export is } \\
\text { selected. }\end{array} \\
\text { 5) Selection criteria of financing body are defined. }\end{array}$ \\
& $\begin{array}{l}\text { 6) Relevant export financing body is selected. } \\
\text { 7) Export financing agreement is concluded. }\end{array}$
\end{tabular}

\section{Base Practices}

BP1: Evaluate external financing needs. Assess exporter's needs of external financing for export operations. [Outcome: 1]

BP2: Identify export financing methods. Identify external financing methods of turnover funds (float) for export of products/services. [Outcome: 2]

BP3: Define comparison criteria of export financing. Define comparison criteria of external financing methods for export of products/services. [Outcome: 3]

BP4: Compare export financing methods. Compare external financing methods for actual export scenario according to defined comparison criteria. [Outcome: 3]

BP5: Select export financing methods. Select external financing methods for actual export scenario according to the defined comparison criteria.[Outcome: 4]

BP6: Define comparison criteria of financing bodies. Define comparison criteria of external financing bodies for financing the selected method export. [Outcome: 5]

BP7: Select a financing body. Select an external financing body according to the defined comparison criteria for financing the selected method export. [Outcome: 6]

BP8: Conclude financing agreement. Conclude external financing agreement for financing export of products/services by the selected external financing methods. [Outcome: 7]

\section{TEChNOLOGY TRANSFER AND EXPORT PROCESSES}

Technology transfer means the transformation of knowledge into value. Such transformation can be inside country or cross-border. Cross-border technology transfer is some kind of export. The research project of the Seventh Framework Program project No. 600680 "ICT Transfer Concept for Adaptation, Dissemination and Local Exploitation of European Research Results in Central Asian Countries" (eINTERASIA) is targeted to cross-border technology transfer.

The sustainability of the main results of project eINTERASIA - cross-border technology transfer concept and eLogistics solution - is related to export activities.

Export process model provided in this paper consists of two process subcategories. The Export preparation subcategory corresponds to the technology transfer concept. The Export opration subcategory is directly linked with eLogistics and contains several processes, such as Delivery terms negociation, Shipping management, Export documentation, Export insurance, that are addressed by project eINTERASIA eLogistics solution.

Export process model presented here provides a roadmap of preparation and operation of export related activities based on world level best practices.

\section{CONCLUSION AND FUTURE RESEARCH}

SPICE and Enterprise SPICE conformant Export process capability assessment model has been developed as an Enterprise SPICE extension. It bridges the gap between abstractions required for the assessment model to be applicable for any export activity and export best practices. But when improving the process the companies need to establish and improve their activity model based on export body of knowledge. Export process capability assessment model provided here contains such a body of knowledge and it is a comprehensive collection of export best practices codified according to capability maturity modeling methodology.

More extensive trials in different business sectors are needed for the appropriate validation of the model.

\section{REFERENCES}

[1] Ibrahim, L., et al. "Enterprise SPICE®: an Integrated Model for Enterprise-wide Assessment and Improvement," Washington Federal Aviation Administration, 2010, p. 184

[2] Roth, A.L., "Strategies for increasing the competitiveness of the IT sector companies," Association for Brazilian Software Excellence Promotion, p. 216, SOFTEX, 2009 (In Portuguese)

[3] Boronowsky, M., Mitasiunas, A., Ragaisis, J. and Woronowicz, T., "An Approach to Development of an Application Dependent SPICE Conformant Process Capability Model," in Software Process Improvement and Capability Determination, Communications in Computer and Information Science, vol. 349, pp. 61-72, 2013. http://dx.doi.org/10.1007/978-3-642-38833-0 6

[4] Besson, J., Mitasiunas, A. and Ragaisis, S., "Enterprise SPICE Export Extension," in Software Process Improvement and Capability Determination, Communications in Computer and Information Science, vol. 477, pp. 279-282, 2014. http://dx.doi.org/10.1007/978-3-31913036-1_27

[5] U. S. Department of Commerce, A Basic Guide to Exporting, 2012 ed., p. 246, [Online]. Available: http://www.export.gov/basicguide/ 
[6] Australian Export Handbook. Australian Institute of Export. 20 2 th ed., p. 609, 2012.

[7] Masandukaite, A., Minalga, R.P., Riepsas, J. and Saltinyte, L., Exporter Guide. Lithuanian economic development agency, 2008 (in Lithuanian).

Jeremy Besson is a System Analyst and Java Developer at MitSoft company. He sometimes works as a Data Mining Consultant. He is also a Data Mining Lecturer at Vilnius University, the Statistic Department. His research interests focus on developing novel data mining techniques for applications in bioinformatics and digital advertising, and process-oriented innovation and export modelling. He was a key participant of the Baltic Sea Region INTERREG program project BONITA.

E-mail: jeremy.besson@gmail.com
Antanas Mitasiunas is the founder and chairman of the board of company MitSoft. He is also an Associate Professor of the Department of Computer Science at Vilnius University. He obtained a Doctoral Degree in Computer Science (Dr. sc. comp.) from Moscow State University in 1981. He was a national expert of the ICT Committee in FP7, member of advisory board of the international project Enterprice SPICE, expert of national European Structural Funds. Research areas: software design, software quality management, innovations and technology transfer.

E-mail: antanas.mitasiunas@mitsoft.lt

Saulius Ragaisis has received a Doctoral Degree in Computer Science (Dr. sc. comp.) from Moscow University in 1994.

Since 1987 he has been working at Vilnius University, currently he is an Associate Professor at the Department of Software Engineering, Faculty of Mathematics and Informatics.

His research interests include software process modeling, software engineering education and electronic signature.

E-mail: saulius.ragaisis@mif.vu.lt 